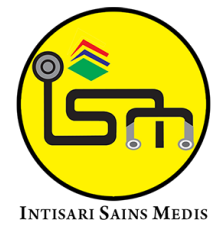

Published by Intisari Sains Medis

\title{
Pencegahan penularan infeksi Human Immunodeficiency Virus (HIV) dari ibu ke anak di Indonesia: sebuah tinjauan pustaka
}

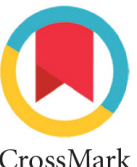

\author{
Komang Ayu Witarini ${ }^{1 *}$
}

\section{ABSTRACT}

Human Immunodeficiency Virus (HIV) can be transmitted from an HIV-positive woman to her child during pregnancy, childbirth, and breastfeeding. Mother-to-child transmission (MTCT), also known as 'vertical transmission', accounts for the vast majority of infection in children (0-14 years). Prevention of motherto-child HIV infection transmission (PMTCT) programs offers a range of services for women of reproductive age (15-49 years) living with or at risk of HIV to maintain their health and stop their infants from acquiring HIV. WHO promotes a comprehensive approach to PMTCT programs which include: preventing new HIV infections among women of reproductive age, preventing unintended pregnancies among women living with HIV, preventing HIV transmission from women living with HIV to her baby, and providing appropriate treatment, care, and support to mothers living with HIV, their children, and families. The health service program to prevent HIV transmission from HIV-infected pregnant women to their babies includes the following activities: integrated ANC services, including offering and testing HIV to pregnant women; HIV diagnosis in pregnant women; administering antiretroviral therapy to pregnant women; safe delivery; arrange for subsequent pregnancies; management of feeding for infants and children; administration of Antiretroviral (ARV) prophylaxis and cotrimoxazole in children; HIV diagnostic testing in children; and immunization. The risk of MTCT of HIV can be reduced to less than $2 \%$ with optimal PMTCT programs.

Keywords: Pregnant Women, HIV Positive, Comprehensive PMTCT

Cite This Article: Witarini, A.Y. 2021. Pencegahan penularan infeksi Human Immunodeficiency Virus (HIV) dari ibu ke anak di Indonesia: sebuah tinjauan pustaka. Intisari Sains Medis 12(2): 601-605. D0I: 10.15562/ism.v12i2.1089

\section{ABSTRAK}

'Sub-Bagian Alergi-Imunologi, Departemen IImu Kesehatan Anak, Fakultas Kedokteran, RS Universitas Udayana, Bali, Indonesia

\section{*Korespondensi:}

Komang Ayu Witarini; Sub-Bagian Alergi-Imunologi, Departemen IImu Kesehatan Anak, Fakultas Kedokteran, RS Universitas Udayana, Bali, Indonesia; ayuwitarini@gmail.com

\section{Diterima: 16-06-2021}

Disetujui: 05-08-2021

Diterbitkan: 20-08-2021
Human Immunodeficiency Virus (HIV) dapat ditularkan dari ibu yang terinfeksi kepada bayi yang dikandung selama kehamilan, persalinan dan menyusui. Penularan infeksi HIV dari ibu kepada bayi yang dikandung, dikenal dengan istilah transmisi vertikal, merupakan cara penularan infeksi tersering dijumpai pada anak usia 0-14 tahun. Program pencegahan penularan infeksi HIV dari ibu ke anak (PPIA) merupakan upaya terhadap perempuan usia produktif(15-49 tahun) yang terinfeksi atau memiliki risiko terinfeksi HIV untuk tetap terjaga kesehatannya, serta mencegah menularkan infeksi HIV kepada bayi yang dikandung. World Health Organization (WHO) mempromosikan upaya komprehensif dari PPIA, terdiri dari: mencegah terjadinya penularan HIV pada perempuan usia reproduksi, mencegah kehamilan yang tidak direncanakan pada perempuan dengan HIV, mencegah terjadinya penularan HIV dari ibu hamil HIV positif ke bayi yang dikandungnya, serta memberikan dukungan psikologis, sosial, dan perawatan kesehatan kepada ibu HIV positif beserta bayi dan keluarganya. Program pelayanan kesehatan untuk mencegah penularan HIV dari ibu hamil terinfeksi HIV kepada bayi yang dikandung mencakup kegiatan sebagai berikut: layanan antenatal care (ANC) terpadu termasuk penawaran dan tes HIV pada ibu hamil; diagnosis HIV pada ibu hamil; pemberian terapi antiretroviral pada ibu hamil; persalinan yang aman; menunda dan mengatur kehamilan berikutnya; tatalaksana pemberian makanan bagi bayi dan anak; pemberian profilaksis Antiretroviral (ARV) dan kotrimoksazol pada anak; pemeriksaan diagnostik HIV pada anak; serta imunisasi. Dengan upaya PPIA yang optimal, risiko penularan HIV dari ibu ke anak dapat diturunkan sampai kurang dari $2 \%$.
Kata kunci: Ibu Hamil, HIV positif, PPIA Komprehensif

Cite This Article: Witarini, A.Y. 2021. Pencegahan penularan infeksi Human Immunodeficiency Virus (HIV) dari ibu ke anak di Indonesia: sebuah tinjauan pustaka. Intisari Sains Medis 12(2): 601-605. D0I: 10.15562/ism.v12i2.1089 


\section{PENDAHULUAN}

Human Immunodeficiency Virus (HIV) merupakan salah satu masalah kesehatan utama yang mempengaruhi angka kematian ibu dan anak di Indonesia. ${ }^{1}$ Peningkatan prevalens infeksi HIV pada perempuan usia reproduksi akan meningkatkan risiko penularan infeksi HIV dari ibu ke anak (PIA). Data Kementrian Kesehatan Republik Indonesia pada tahun 2020 menunjukkan jumlah komulatif infeksi HIV pada perempuan yang dilaporkan sampai trimester ketiga 2020 adalah 155.745 orang. Berdasarkan kelompok umur, secara konsisten didapatkan prevalens tertinggi pada kelompok umur 25-49 tahun setiap tahunnya. ${ }^{1}$

Lebih dari 90\% kasus anak terinfeksi HIV ditularkan melalui penularan vertikal dari ibu ke anak. ${ }^{2,3}$ Jumlah kasus HIV pada anak di Indonesia terus meningkat setiap tahun, pada tahun 2016 ditemukan 7238 anak dengan HIV dan pada tahun 2020 jumlah kasus mencapai 26.640, jumlah ini merupakan 6,5\% dari seluruh kasus HIV di Indonesia. ${ }^{1}$

Pencegahan PIA (PPIA) atau PMTCT telah terbukti sebagai intervensi yang sangat efektif untuk mencegah penularan HIV dari ibu ke anak. Risiko anak tertular HIV dari ibu dapat ditekan hingga kurang dari $2 \%$ dengan tersedianya intervensi PPIA yang optimal. ${ }^{4,5}$ Risiko penularan di negara berkembang, termasuk Indonesia, masih cukup tinggi, yaitu berkisar antara 20-50\%. Hal ini disebabkan oleh karena minimnya akses intervensi. ${ }^{6}$

Berdasarkan pada pemaparan di atas, tinjauan kepustakaan ini bertujuan untuk melakukan evaluasi pencegahan penularan infeksi HIV dari ibu ke anak di Indonesia dengan menerapkan beberapa strategi manajemen komprehensif terkini berdasarkan studi kepustakaan.

\section{DEFINISI HIV}

HIV adalah virus yang menyebabkan Acquired Immune Deficiency Syndrome (AIDS). Virus termasuk dalam kelompok rotavirus. Seseorang yang terinfeksi HIV akan mengalami infeksi seumur hidup, sebagian besar tidak menunjukkan gejala klinis selama bertahun-tahun, namun tetap dapat menularkan infeksi kepada orang lain. Penularan infeksi HIV dari ibu ke anak (PIA/MTCT) adalah penularan infeksi HIV dari ibu hamil yang terinfeksi kepada bayi yang dikandung selama proses kehamilan, persalinan, dan pasca persalinan saat menyusui. Program pencegahan penularan HIV dari ibu ke anak (PPIA/PMTCT) adalah upaya yang dilakukan untuk mencegah penularan infeksi HIV dari ibu ke anak. ${ }^{7,8}$

\section{PENULARAN VERTIKAL HIV DARI IBU KE ANAK}

HIV dapat ditularkan dari ibu yang terinfeksi ke anak selama kehamilan, saat persalinan, dan menyusui. Selama kehamilan, sirkulasi darah janin dan ibu dipisahkan oleh lapisan sel yang terdapat pada plasenta. Plasenta dapat melindungi janin dari infeksi HIV, namun jika terjadi peradangan, infeksi ataupun kerusakan pada plasenta, maka HIV dapat menembus plasenta sehingga terjadi penularan HIV dari ibu ke anak. ${ }^{9}$ Risiko penularan HIV selama kehamilan adalah sebesar 5-10\%. Risiko penularan lebih besar didapatkan pada saat persalinan (10-20\%) dan menyusui (5-20\%), Risiko penularan HIV dari ibu ke anak secara keseluruhan adalah 20-50\%. Risiko penularan ini dapat diturunkan menjadi kurang dari $2 \%$ dengan PPIA yang optimal. ${ }^{8}$

Tiga faktor utama yang mempengaruhi penularan HIV dari ibu ke anak adalah faktor ibu, bayi atau anak, dan tindakan obstetrik. Faktor ibu, yaitu: (1) jumlah virus (viral load) dalam darah ibu menjelang atau saat persalinan dan dalam air susu ibu ketika ibu menyusui bayi, risiko penularan rendah jika jumlah virus kurang dari $1.000 \mathrm{kopi} / \mathrm{ml}$ dan sebaliknya jika jumlah virus di atas 100.000 kopi/ $\mathrm{ml}$; (2) jumlah sel CD4 Ibu, risiko penularan semakin besar pada jumlah sel CD4 yang rendah; (3) status gizi selama kehamilan, berat badan rendah serta kekurangan vitamin dan mineral selama kehamilan meningkatkan risiko ibu untuk menderita penyakit infeksi sehingga dapat meningkatkan jumlah virus dan risiko penularan; (4) penyakit infeksi selama kehamilan meningkatkan jumlah virus dan risiko penularan; (5) gangguan pada payudara ibu meningkatkan risiko penularan melalui ASI. ${ }^{10-12}$

Faktor bayi atau anak yang mempengaruhi penularan HIV dari ibu terinfeksi ke anak adalah: (1) usia kehamilan dan berat badan bayi saat lahir, prematur dan Berat Badan Lahir Rendah (BBLR) meningkatkan risiko penularan karena sistem organ dan kekebalan tubuh bayi belum berkembang dengan baik; (2) periode pemberian ASI, semakin lama ibu menyusui, maka risiko penularan akan semakin besar; dan (3) perlukaan di mulut bayi meningkatkan risiko penularan saat diberikan ASI. ${ }^{13,14}$

Faktor obstetrik juga memegang peranan penting dalam penularan HIV dari ibu ke anak, diantaranya: (1) jenis persalinan, risiko penularan pada persalinan per vaginam lebih besar daripada bedah sesar (seksio sesaria); (2) lama persalinan, semakin lama proses persalinan berlangsung, maka risiko penularan semakin tinggi, karena semakin lama terjadinya kontak antara bayi dengan darah dan lendir ibu; (3) ketuban pecah lebih dari 4 jam sebelum persalinan meningkatkan risiko penularan hingga dua kali lipat dibandingkan ketuban pecah kurang dari 4 jam; dan (4) tindakan episiotomi, ekstraksi vakum dan forseps meningkatkan risiko penularan HIV karena berpotensi melukai ibu atau bayi. ${ }^{15,16}$

\section{PENCEGAHAN PENULARAN HIV DARI IBU KE ANAK}

Menurut WHO terdapat 4 upaya yang harus dilakukan untuk mencegah terjadinya penularan HIV dari ibu ke anak (4 Prong), meliputi: (1) mencegah terjadinya penularan HIV pada perempuan usia reproduksi; (2) mencegah kehamilan yang tidak direncanakan pada perempuan dengan HIV; (3) mencegah terjadinya penularan HIV dari ibu hamil HIV positif ke bayi yang dikandungnya; (4) memberikan dukungan psikologis, sosial, dan perawatan kesehatan selanjutnya kepada ibu HIV positif beserta bayi dan keluarganya. ${ }^{2}$ Adapun beberapa Langkah yang direkomendasikan oleh WHO di atas akan dijabarkan sesuai dengan penjelasan berikut.

\section{Pencegahan penularan HIV pada perempuan usia reproduksi}

Langkah dini yang paling efektif untuk mencegah terjadinya penularan HIV pada 
anak adalah dengan mencegah penularan HIV pada perempuan usia reproduksi (pencegahan primer). Upaya pencegahan primer yang dapat dilakukan adalah dengan menghindari perilaku seksual yang berisiko, yaitu dengan cara: (1) tidak melakukan hubungan seksual bagi orang yang belum menikah; (2) bersikap setia kepada satu pasangan seksual (tidak berganti pasangan); (3) mencegah penularan HIV melalui hubungan seksual dengan menggunakan kondom; dan (4) tidak menggunakan narkoba. ${ }^{8}$

\section{Pencegahan kehamilan yang tidak direncanakan pada perempuan dengan HIV}

Setiap kehamilan yang terjadi pada ibu dengan HIV harus direncanakan, oleh karena berpotensi menularkan virus kepada bayi yang dikandung. Upaya yang dapat dilakukan untuk merencanakan kehamilan pada ibu yang terinfeksi HIV adalah: (1) memberikan informasi mengenai HIV-AIDS dan perilaku seksual yang aman; (2) memberikan konseling dan tes HIV untuk pasangan; (3) melakukan upaya pencegahan dan pengobatan penyakit infeksi menular seksual; (4) melakukan promosi penggunaan kondom; (5) memberikan konseling pada perempuan dengan HIV untuk ikut KB dengan menggunakan metode kontrasepsi dan cara yang tepat; dan (6) memberikan konseling dan memfasilitasi perempuan dengan HIV yang ingin merencanakan kehamilan. $^{8}$

\section{Pencegahan penularan HIV dari ibu hamil HIV positif ke bayi yang dikandungnya}

Pelayanan kesehatan ibu dan anak yang komprehensif merupakan strategi efektif untuk mengidentifikasi ibu hamil terinfeksi HIV, serta mengurangi risiko penularan HIV dari ibu ke anak pada periode kehamilan, persalinan, dan pasca kelahiran. Pelayanan kesehatan mencakup kegiatan sebagai berikut: (1) layanan Antenatal Care (ANC) terpadu termasuk penawaran dan tes HIV pada ibu hamil; (2) diagnosis HIV pada ibu hamil; (3) pemberian terapi antiretroviral pada ibu hamil; (4) persalinan yang aman; (5) menunda dan mengatur kehamilan berikutnya; (6) tatalaksana pemberian makanan bagi bayi dan anak; (7) pemberian profilaksis Antiroviral (ARV) dan kotrimoksazol pada anak; dan (8) pemeriksaan diagnostik HIV pada anak; (9) imunisasi. ${ }^{8}$

Pelayanan ANC terpadu (penawaran dan tes HIV pada ibu hamil) yang dimaksudkan adalah upaya membuka akses bagi ibu hamil untuk mengetahui status HIV, sehingga dapat melakukan upaya untuk mencegah penularan HIV dari ibu ke anak, memperoleh pengobatan ARV sedini mungkin, dukungan psikologis, informasi, dan pengetahuan tentang HIV-AIDS. Kemudian diagnosis HIV pada ibu hamil dapat dilakukan dengan pemeriksaan diagnostik infeksi HIV secara virologis (mendeteksi Deoxyribonucleic Acid (DNA) atau Ribonucleic Acid (RNA) virus HIV) dan serologis (mendeteksi antibodi HIV) pada spesimen darah. Pemeriksaan diagnostik infeksi HIV pada ibu hamil yang dilakukan di Indonesia umumnya adalah pemeriksaan serologis menggunakan tes cepat (rapid test HIV) atau enzyme-linked immunosorbent assay (ELISA). Sedangkan pemberian ARV pada ibu hamil dengan HIV bertujuan untuk mengurangi risiko penularan HIV dari ibu ke anak dan mengoptimalkan kondisi kesehatan ibu dengan cara menurunkan kadar HIV serendah mungkin. Semua ibu hamil dengan HIV harus mendapat terapi ARV tanpa memandang jumlah CD4, karena kehamilan sendiri merupakan indikasi pemberian ARV yang dilanjutkan seumur hidup.

Pilihan terapi yang direkomendasikan untuk ibu hamil dengan HIV adalah menggunakan kombinasi tiga obat, yaitu 2 Nucleoside Reverse Transcriptase Inhibitor (NRTI) dan 1 Non-Nucleoside Reverse Transcriptase Inhibitor (NNRTI). Sangat tidak dianjurkan untuk menggunakan 3 NRTI. Semua obat yang dipakai harus dimulai pada saat yang bersamaan pada pasien baru. Terapi kombinasi ARV harus menggunakan dosis dan jadwal yang tepat. Obat ARV harus diminum secara teratur untuk menghindari timbulnya resistensi. Regimen ARV yang direkomendasikan pada ibu hamil dapat dilihat pada Tabel 1.

\section{Persalinan yang aman}

Pemilihan persalinan yang aman diputuskan oleh ibu setelah mendapatkan konseling lengkap tentang pilihan persalinan, risiko penularan, dan berdasarkan penilaian dari tenaga kesehatan. Pilihan persalinan meliputi

\section{Tabel 1. Rekomendasi ARV pada ibu hamil dengan HIV ${ }^{8}$}

\begin{tabular}{|c|c|c|}
\hline No. & Kondisi & Rekomendasi pengobatan \\
\hline \multirow[t]{5}{*}{1.} & - ODHA hamil, segera & - $\mathrm{TDF}(300 \mathrm{mg})+3 \mathrm{TC}(300 \mathrm{mg})+\mathrm{EFV}(600 \mathrm{mg})$ \\
\hline & terapi ARV & Alternatif: \\
\hline & $\begin{array}{l}\text { - ODHA datang pada masa } \\
\text { persalinan dan belum } \\
\text { mendapat terapi ARV, }\end{array}$ & $\begin{array}{l}\text { AZT }(2 \times 300 \mathrm{mg})+3 \mathrm{TC}(2 \times 150 \mathrm{mg})+\mathrm{NVP} \\
(1 \mathrm{x} 200 \mathrm{mg} \text { setelah } 2 \text { minggu } 2 \times 200 \mathrm{mg})\end{array}$ \\
\hline & $\begin{array}{l}\text { lakukan tes, bila hasil } \\
\text { reaktif berikan ARV }\end{array}$ & $\begin{array}{l}\text { - TDF }(1 \times 300 \mathrm{mg})+3 \text { TC (atau FTC) }(2 \times 150 \mathrm{mg})+ \\
\operatorname{NVP}(2 \times 200 \mathrm{mg})\end{array}$ \\
\hline & & $\begin{array}{l}\text { - } \mathrm{AZT} \mathrm{(2x300mg)} \mathrm{+} \mathrm{3TC} \mathrm{(2x150mg)} \mathrm{+} \mathrm{EFV} \\
(1 \times 600 \mathrm{mg})\end{array}$ \\
\hline 2. & $\begin{array}{l}\text { ODHA sedang menggunakan } \\
\text { ARV dan kemudian hamil }\end{array}$ & $\begin{array}{l}\text { - Lanjutkan dengan ARV yang sama selama dan } \\
\text { sesudah persalinan }\end{array}$ \\
\hline \multirow[t]{2}{*}{3.} & $\begin{array}{l}\text { ODHA hamil dengan } \\
\text { hepatitis } \mathrm{B} \text { yang memerlukan }\end{array}$ & $\begin{array}{l}\text { - TDF }(1 \times 300 \mathrm{mg})+3 \mathrm{TC}(\text { atau FTC })(1 \times 300 \mathrm{mg})+ \\
\text { EFV }(1 \times 600 \mathrm{mg}) \text { atau }\end{array}$ \\
\hline & terapi & $\begin{array}{l}\text { - TDF }(1 \times 300 \mathrm{mg})+3 \mathrm{TC}(\text { atau FTC) }(2 \times 150 \mathrm{mg})+ \\
\operatorname{NVP}(2 \times 200 \mathrm{mg})\end{array}$ \\
\hline \multirow[t]{2}{*}{4.} & $\begin{array}{l}\text { ODHA hamil } \\
\text { tuberkulosis aktif }\end{array}$ & $\begin{array}{l}\text { - Bila OAT sudah diberikan, maka dilanjutkan. Bila } \\
\text { belum diberikan, maka OAT diberikan terlebih } \\
\text { dahulu sebelum pemberian ARV. }\end{array}$ \\
\hline & & $\begin{array}{l}\text { - Rejimen untuk ibu bila OAT sudah diberikan dan } \\
\text { tuberculosis telah stabil: TDF + 3TC + EFV }\end{array}$ \\
\hline
\end{tabular}

AZT/ZDV: zidovudine; 3TC: lamivudine; FTC: emtricitabine; NVP: nevirapine; $\mathrm{EFV}$ : evavirenz; TDF: tenovofir; ODHA: Orang dengan HIV/AIDS 
persalinan per vaginam dan per abdominam (bedah sesar atau seksio sesarea). Persalinan per vaginam dapat dipilih bila terapi ARV sudah dimulai sejak usia kehamilan 14 minggu dan kadar HIV $<1000 \mathrm{kopi} / \mu \mathrm{L}$, atau bila fasilitas bedah sesar tidak tersedia. Beberapa hasil penelitian telah membuktikan bahwa persalinan perabdominal (bedah sesar) memiliki risiko penularan lebih kecil jika dibandingkan dengan persalinan per vaginam. Bedah sesar dapat mengurangi risiko penularan HIV dari ibu ke bayi hingga sebesar $2 \%-4 \% .{ }^{15-17}$

\section{Menunda dan mengatur kehamilan selanjutnya}

Jenis kontrasepsi yang dipilih untuk ibu dengan HIV harus selalu disertai penggunaan kondom untuk mencegah HIV dan infeksi penyakit menular seksual (PMS). Ibu yang ingin menunda atau mengatur kehamilan dapat menggunakan kontrasepsi jangka panjang, sedangkan ibu yang memutuskan tidak punya anak lagi, dapat memilih kontrasepsi mantap.

\section{Tatalaksana pemberian makanan bagi bayi dan anak}

Pemilihan makanan bayi harus didahului dengan konseling tentang risiko penularan HIV melalui air susu ibu (ASI). Konseling diberikan sejak perawatan antenatal atau sebelum persalinan. Pengambilan keputusan oleh ibu dilakukan setelah mendapat informasi secara lengkap. World Health Organization (WHO) merekomendasikan pemberian ASI eksklusif selama 6 bulan untuk bayi lahir dari ibu dengan HIV dan sudah dalam terapi ARV untuk kelangsungan hidup anak (HIV-free and child survival). ${ }^{18}$ Setelah bayi berusia 6 bulan pemberian ASI dapat diteruskan hingga bayi berusia 12 bulan, disertai dengan pemberian makanan padat.

Bila ibu tidak dapat memberikan ASI eksklusif, maka ASI harus dihentikan dan digantikan dengan susu formula untuk menghindari mixed feeding. Mixed feeding artinya diberikan ASI dan pendamping ASI (PASI) atau susu formula bergantian. Mixed feeding sangat tidak dianjurkan, karena pemberian susu formula yang merupakan benda asing bagi dinding usus bayi dapat menimbulkan perubahan mukosa dinding usus, sehingga mempermudah masuknya HIV yang ada di dalam ASI ke peredaran darah bayi. Pemberian susu formula harus memenuhi kriteria AFASS, yaitu acceptable (diterima), feasible (terlaksana), affordable (terjangkau), sustainable (berkesinambungan), dan safe (aman, bersih, berkualitas). Beberapa studi menunjukkan pemberian susu formula merupakan cara pemberian makanan yang paling aman. Perbandingan risiko penularan HIV pada pemberian susu formula, ASI esklusif, dan mixed feeding adalah susu formula (0\%), ASI esklusif (5-15\%), dan mixed feeding $(24,1 \%){ }^{13,14}$ Adapun rekomendasi Ikatan Dokter Anak Indonesia (IDAI) berkaitan dengan nutrisi untuk bayi dari ibu HIV positif adalah dengan pemilihan adalah susu formula untuk mencegah penularan HIV dari ibu ke anak serta mixed feeding harus dihindari karena memiliki risiko penularan HIV dari ibu ke anak lebih tinggi dibandingkan dengan ASI ekslusif dan susu formula. ${ }^{19}$

\section{Profilaksis ARV dan kotrimoksasol pada anak}

Semua bayi yang lahir dari ibu terinfeksi HIV harus mendapat ARV profilaksis setelah lahir untuk mencegah penularan infeksi dari ibu ke anak. Pemberian profilaksis ARV dimulai hari pertama setelah lahir, pemberian sebaiknya dalam 6-12 jam setelah kelahiran. Profilaksis ARV diberikan selama 6 minggu. Selanjutnya anak diberikan profilaksis kotrimoksazol mulai usia 6 minggu sampai diagnosis HIV ditegakkan. ${ }^{8,19}$ Adapun rekomendasi IDAI dalam pemberian ARV dan kotrimoksasol profilaksis pada bayi dari ibu HIV positif meliputi: 1) Bayi mendapat susu formula dapat diberikan zidovudine selama 6 minggu; 2) Bayi mendapat ASI eksklusif dapat diberikan zidovudine dan nevirapine selama 6 minggu (ASI dapat diberikan selama ibu minum ARV); dan 3) Profilaksis kotrimoksasol harus diberikan pada semua bayi yang lahir dari ibu dengan HIV mulai usia 6 minggu sampai diagnosis HIV ditegakkan. ${ }^{19}$

Zidovudine untuk profilaksis diberikan peroral setiap 12 jam. Dosis ditentukan berdasarkan usia gestasi bayi, yaitu usia gestasi $\geq 35$ minggu: $4 \mathrm{mg} / \mathrm{kg} /$ dosis, usia gestasi $\geq 30$ minggu sampai $<35$ minggu: $2 \mathrm{mg} / \mathrm{kg} /$ dosis dilanjutkan dengan dosis 3 $\mathrm{mg} / \mathrm{kg} /$ dosis saat usia 15 hari, usia gestasi $<30$ minggu: $2 \mathrm{mg} / \mathrm{kg} /$ dosis dilanjutkan dengan dosis $3 \mathrm{mg} / \mathrm{kg} / \mathrm{dosis}$ saat usia 4 minggu. Dosis nevirapine ditentukan berdasarkan berat badan bayi saat lahir, yaitu 1500-2000 gram: $8 \mathrm{mg} /$ dosis, 20002499 gram: $10 \mathrm{mg} /$ dosis, $\geq 2500$ gram: $15 \mathrm{mg} /$ dosis. Kotrimoksasol profilaksis diberikan dengan dosis $4-6 \mathrm{mg} / \mathrm{kg} /$ dosis peroral setiap 24 jam. $^{19}$

\section{Pemeriksaan diagnostik HIV pada anak}

Antibodi HIV dari ibu dapat berpindah ke bayi melalui plasenta selama kehamilan. Antibodi HIV ibu akan berada pada darah bayi/anak hingga usia 18 bulan, sehingga penentuan status HIV pada bayi/anak usia $<18$ bulan tidak dapat dilakukan dengan cara pemeriksaan serologi anti-HIV. Pemeriksaan serologis anti-HIV dilakukan setelah anak berusia 18 bulan atau dapat dilakukan lebih awal pada usia 9-12 bulan, dengan catatan bila hasilnya positif, maka harus diulang setelah anak berusia 18 bulan. Pemeriksaan virologis, yaitu HIV DNA melalui Polymerase Chain Reaction (PCR), saat ini sudah ada di Indonesia dan dapat digunakan untuk menegakkan diagnosis HIV pada anak usia di bawah 18 bulan. Pemeriksaan tersebut harus dilakukan minimal 2 kali, dapat dimulai ketika bayi berusia 4-6 minggu dan perlu diulang 4 minggu kemudian. ${ }^{8}$

\section{Imunisasi pada bayi dengan ibu HIV positif}

Sebagian besar bayi lahir dari ibu terinfeksi HIV yang mendapat program PPIA memiliki status infeksi HIV negatif, dengan risiko penularan kurang dari $2 \%$. Imunisasi dapat diberikan sesuai dengan jadwal nasional, kecuali untuk imunisasi Bacille Calmette Guerin (BCG), hanya diberikan bila bayi terbukti tidak terinfeksi HIV. Berdasarkan rekomendasi penelitian sebelumnya, imunisasi BCG tidak diberikan pada bayi yang terinfeksi HIV karena risiko untuk terjadinya efek samping yang berat lebih besar daripada manfaat imunisasi. ${ }^{20}$ Adapun beberapa rekomendasi IDAI terkait dengan pemberian imunisasi pada bayi dari ibu HIV positif seperti: 1) Vaksin 
dapat diberikan pada bayi yang lahir dari ibu terinfeksi HIV sesuai dengan jadwal imunisasi nasional; 2) Vaksin BCG dapat diberikan pada bayi yang lahir dari ibu terinfeksi HIV setelah terbukti tidak terinfeksi HIV; dan 3) Campak dan vaksin polio oral dapat diberikan pada bayi sehat yang lahir dari ibu terinfeksi HIV. ${ }^{19}$

\section{Pemberian dukungan psikologis, sosial, dan perawatan kesehatan selanjutnya kepada ibu HIV positif beserta bayi dan keluarganya}

Upaya pencegahan penularan HIV dari ibu ke anak tidak berhenti setelah ibu melahirkan. Ibu akan hidup dengan HIV di tubuhnya. Ia membutuhkan dukungan psikologis, sosial dan perawatan sepanjang waktu. Hal ini terutama karena ibu akan menghadapi masalah stigma dan diskriminasi masyarakat terhadap penderita HIV. Faktor kerahasiaan status HIV ibu sangat penting dijaga. Dukungan juga harus diberikan kepada anak dan keluarganya.

Dengan dukungan psikososial yang baik, ibu dengan HIV akan bersikap optimis dan bersemangat mengisi kehidupannya. Diharapkan ia akan bertindak bijak dan positif untuk senantiasa menjaga kesehatan diri dan anaknya, serta berperilaku sehat agar tidak terjadi penularan HIV dari dirinya ke orang lain.

\section{SIMPULAN}

Penularan HIV dari ibu ke anak merupakan masalah kesehatan secara global di dunia. Penularan HIV dapat terjadi selama kehamilan, proses persalinan, dan menyusui. Mencegah terjadinya penularan HIV dari ibu terinfeksi HIV ke anak yang dikandung merupakan inti dari kegiatan PPIA. Upaya yang dapat dilakukan adalah menawarkan kepada semua ibu hamil untuk dilakukan tes HIV (pencegahan primer), pemberian ARV pada ibu hamil HIV positif, pemilihan kontrasepsi yang sesuai untuk perempuan HIV positif, pemilihan persalinan aman untuk ibu hamil HIV positif, pemberian ARV profilaksis dan makanan terbaik bagi bayi yang lahir dari ibu HIV positif. Dengan upaya PPIA yang optimal, risiko penularan HIV dari ibu ke anak dapat diturunkan sampai kurang dari $2 \%$.

\section{KONFLIK KEPENTINGAN}

Tidak terdapat konflik kepentingan dalam penyusunan tinjauan kepustakaan ini.

\section{ETIKA PENULISAN}

Tinjauan kepustakaan ini telah memenuhi kaidah etika publikasi berdasarkan pada pedoman COPE dan ICMJE dalam pencarian literatur yang relevan sebelum publikasi pada jurnal ilmiah.

\section{PENDANAAN}

Tidak ada.

\section{KONTRIBUSI PENULIS}

Seluruh penulis memiliki kontribusi yang sama dalam penyusunan kerangka konsep, pencarian literatur, analisis dan sintesis, hingga penyusunan naskah tinjauan kepustakaan dalam publikasi ilmiah.

\section{DAFTAR PUSTAKA}

1. Ditjen P2P Kemenkes RI. Laporan perkembangan HIV-AIDS \& PIMS triwulan III tahun 2020 di Indonesia [Internet]. 2020. [Diakses pada: http://www.siha.kemkes.go.id]

2. World Health Organization. PMTCT strategic vision 2010-2015: preventing mother-to-child transmission of HIV to reach the UNGASS and millennium development goals. Geneva: World Health Organization. 2010.

3. Shetty AK. Epidemiology of HIV infection in women and children: a global perspective. Curr HIV Res. 2013;11(2):81-92.

4. Ackerman Gulaid L, Kiragu K. Lessons learnt from promising practices in community engagement for the elimination of new HIV infections in children by 2015 and keeping their mothers alive: summary of a desk review. J Int AIDS Soc. 2012;15 Suppl 2(Suppl 2):17390.

5. Negara IKS, Anantasika AAN, Putra A, Wiradnyana AAP, Tunas IK. Characteristics of pregnant women with HIV infection following Prevention of Mother to Child Transmission of HIV (PMTCT) program in Sanglah general hospital 2005-2014. Bali Medical Journal. 2016;5(1):147-151.

6. De Cock KM, Fowler MG, Mercier E, de Vincenzi I, Saba J, Hoff E, et al. Prevention of mother-to-child HIV transmission in resourcepoor countries: translating research into policy and practice. JAMA. 2000;283(9):1175-82.
7. Volmink J, Marais B. HIV: mother-to-child transmission. BMJ Clin Evid. 2008;2:909-30.

8. Lumbantoruan C, Kelaher M, Kermode M, Budihastuti E. Pregnant women's retention and associated health facility characteristics in the prevention of mother-to-child HIV transmission in Indonesia: cross-sectional study. BMJ Open. 2020;10(9):e034418.

9. Spector SA. Mother-to-infant transmission of HIV-1: the placenta fights back. J Clin Invest. 2001;107(3):267-269.

10. Ioannidis JP, Abrams EJ, Ammann A, Bulterys M, Goedert JJ, Gray L, et al. Perinatal transmission of human immunodeficiency virus type 1 by pregnant women with RNA virus loads $<1000$ copies/ml. J Infect Dis. 2001;183(4):539-45.

11. Ngwende S, Gombe NT, Midzi S, Tshimanga M, Shambira G, Chadambuka A. Factors associated with HIV infection among children born to mothers on the prevention of mother to child transmission programme at Chitungwiza Hospital, Zimbabwe, 2008. BMC Public Health. 2013;13:1181.

12. de Lemos LM, Lippi J, Rutherford GW, Duarte GS, Martins NG, Santos VS, et al. Maternal risk factors for HIV infection in infants in northeastern Brazil. Int J Infect Dis. 2013;17(10):e913-8.

13. Dong Y, Guo W, Gui X, Liu Y, Yan Y, Feng L, et al. Preventing mother to child transmission of HIV: lessons learned from China. BMC Infect Dis. 2020;20(1):792.

14. Horvath T, Madi BC, Iuppa IM, Kennedy GE, Rutherford G, Read JS. Interventions for preventing late postnatal mother-to-child transmission of HIV. Cochrane Database Syst Rev. 2009;2009(1):CD006734.

15. European Collaborative Study. Caesarean section and the risk of vertical transmission of HIV-1 infection. Lancet 1994;343(8911):14641467.

16. Mark S, Murphy KE, Read S, Bitnun A, Yudin MH. HIV mother-to-child transmission, mode of delivery, and duration of rupture of membranes: experience in the current era. Infect Dis Obstet Gynecol. 2012;2012:267969.

17. European Collaborative Study. Mother-tochild transmission of HIV infection in the era of highly active antiretroviral therapy. Clin Infect Dis. 2005;40(3):458-465.

18. World Health Organization. Guidelines on HIV and Infant Feeding 2010: Principles and Recommendations for Infant Feeding in the Context of HIV and a Summary of Evidence. Geneva: World Health Organization; 2010.

19. Dina M. Update recommendation on prevention of mother-to-child HIV transmission in Indonesia. Konika ke-17; Yogyakarta. 2017

20. Nuttall JJ, Eley BS. BCG Vaccination in HIV-Infected Children. Tuberc Res Treat. 2011;2011:712736.

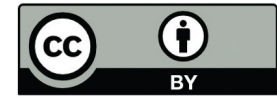

This work is licensed under a Creative Commons Attribution 